\title{
The State Duty to Protect against HUMAN RIGHTS VIOLATIONS THROUGH TRANSNATIONAL BUSINESS ACTIVITIES
}

\author{
MARKUS KRAJEWSKI ${ }^{*}$
}

Transnational corporations are currently not formally bound by international human rights obligations. Instead, states have a duty to protect individuals against human rights abuses by third parties, including corporations. While it is undisputed that this obligation extends to all individuals living on the territory of the respective state, the extraterritorial scope of the duty to protect remains contested. This is especially the case for human rights violations through transnational business activities. The state on whose territory the violation occurs has a duty to protect human rights by adopting and implementing labour and environmental laws applicable in that state. However, it is less clear if and to what extent the state of the main seat of the mother company or the global ordering company - the 'home state' - also has a human rights duty to regulate transnational business activity. This article argues that such a duty can be based on existing human rights doctrine and standards of general international law such as the 'no harm' rule and the due diligence principle. It argues that states have a duty to regulate transnational business activities of corporations over which they exercise jurisdiction if human rights violations caused by such activities are predictable and preventable. In its final part, the article assesses various approaches in state practice which could be seen as instruments in the fulfilment of the duty to regulate transnational business activities

\section{INTRODUCTION}

Fire disasters in textile factories in Pakistan or environmental pollution due to oil leakages in the Niger delta in Nigeria demonstrate clearly that global business activities are often closely associated with human rights violations. However, according to conventional international law doctrine, neither multinational enterprises nor local companies are directly bound by

\footnotetext{
${ }^{*}$ Professor of Public and International Law, University of Erlangen-Nürnberg.
} 
international human rights obligations. ${ }^{1}$ Only states have direct duties based on international human rights law. These human rights obligations comprise the duty to protect individuals against human rights violations committed by third parties, including business enterprises.

Predominantly, this duty to protect rests on the state in which the human rights violation took place. As that state is often seen as lacking the necessary capacities to regulate multinational companies or enforce existing regulations, or is unwilling to do so, human rights activists and scholars are increasingly arguing that the home states of multinational companies also have a duty to regulate the extraterritorial activities of companies domiciled in their jurisdiction in order to prevent human rights violations or mitigate their consequences. In the human rights literature this approach is discussed under the heading 'extraterritorial obligations' (ETOs) of states. ${ }^{2}$ However, it will be argued that the term 'extraterritorial' is misleading as states do not impose regulations on, or enforce their laws in, other territories. Similarly, debates focusing on the scope of the jurisdiction of states in the context of human rights treaties are arguably missing the point.

The present article will analyse whether, and to what extent, states have a duty to regulate the activities of companies of a transnational character in fulfilment of the duty to protect against human rights violations. The article is organised as follows: Part II introduces a framework to assess a company's obligations and responsibilities with regard to human rights violations occurring in the course of transnational business activities. In Part III the general framework of human rights obligations, including their extraterritorial dimensions as developed in recent jurisprudence and doctrine, will be briefly recalled. Part IV then seeks to establish the case for a state duty to regulate transnational business activities. It will distinguish the different roles and functions of home and host states and discuss both human rights and general international law doctrines

\footnotetext{
${ }^{1}$ Alexandra Gatto, Multinational Enterprises and Human Rights (Edward Elgar, 2011) 93; James Crawford, Brownlie's Principles of Public International Law (OUP, $8^{\text {th }}$ ed, 2012) 122; Peter Muchlinski, Multinational Enterprises \& the Law (OUP, $2^{\text {nd }}$ ed, 2007) 515. For different views see Andrew Clapham, Human Rights Obligations of Non-State Actors (OUP, 2006) Chapter 6 and Adam McBeth, International Economic Actors and Human Rights (Routledge, 2010) 58.

${ }^{2}$ See eg Robert McCorquodale and Penelope Simons, 'Responsibility Beyond Borders: State Responsibility for Extraterritorial Violations by Corporations of International Human Rights Law' (2007) 70 Modern Law Review 598, 602; Daniel Augenstein and David Kinley, 'When Human Rights 'Responsibilities' Become 'Duties': The Extraterritorial Obligations of States that Bind Corporations' in Surya Deva and David Bilchitz (eds), Human Rights Obligations of Business: Beyond the Corporate Responsibility to Respect? (CUP, 2013) 271. For a critical review of these arguments see Claire Methven O'Brien, 'The Home State Duty to Regulate the Human Rights Impacts of TNCs Abroad: A Rebuttal' (2018) 3 Business and Human Rights Journal 47.
} 
which can serve as a basis for a home state's duty to regulate. Part IV will also address whether there are any limitations to such a duty based on the principle of non-intervention. In Part V the article will analyse various instruments which have been developed in recent state practice and which could be seen as examples of how states can discharge their obligations to protect against human rights violations caused by transnational business activities.

\section{A Framework to Assess Human Rights VIOLATIONS THROUGH TRANSNATIONAL BUSINESS ACTIVITIES}

Attempts to address the behaviour of transnational business entities through international norms and guidelines date back to the 1970s. ${ }^{3}$ These norms and guidelines would normally address multinational enterprises or transnational corporations. More recent approaches cover multinational enterprises and other business entities. ${ }^{4}$ The reason for this broader approach is that many transnational business transactions which potentially have negative effects on human rights are not conducted within the network of one multinational enterprise, but within global supply chains. Addressing human rights violations in the supply chain has therefore become a key concern in recent years.

It is suggested that in general two types of relationship need to be distinguished. They are exemplified in two scenarios. The first scenario concerns activities which are conducted within a network of companies and corporations forming a multinational enterprise. ${ }^{5}$ The main legal elements of this scenario are transnational corporate relationships. A typical example of a human rights violation in this context would be a locally incorporated subsidiary of a multinational enterprise contributing to the pollution of the environment, thus violating the right to health ${ }^{6}$ and possibly the right to adequate living conditions $^{7}$ of the local people if the pollution destroys farmland or fisheries. If the pollution took place because the mother company did not exercise sufficient

${ }^{3}$ These include the OECD Guidelines for Multinational Enterprises and the work of the United Nations Commission on Transnational Corporations.

${ }^{4}$ Report of the Special Representative of the Secretary-General on the Issue of Human Rights and Transnational Corporations and Other Business Enterprises, Guiding Principles on Business and Human Rights: Implementing the United Nations 'Protect, Respect and Remedy' Framework, UN Doc A/HRC/17/31 (21 March 2011) ('Guiding Principles').

${ }^{5}$ For a more detailed discussion see Muchlinski, above n 1, 56-76.

${ }^{6}$ As established in, inter alia, the International Covenant on Economic, Social and Cultural Rights, art 12.

${ }^{7}$ As established in, inter alia, the International Covenant on Economic, Social and Cultural Rights, art 11. 
oversight, tacitly accepted the activities of the local subsidiary, or even actively encouraged them, one can argue that the mother company caused or contributed to the violations of human rights. ${ }^{8}$

The second scenario concerns activities which take place along a global supply chain. The enterprises of the supply chain are not connected with each other through corporate relationships, but usually through contractual agreements specifying the details of a product, its production or distribution. ${ }^{9}$ A typical example of a human rights violation in this context would be a locally incorporated supplier of a global ordering company (the buyer) employing unsafe working practices because the buyer requires fast and cheap production. In this case, the local supplier could violate the right to safe working conditions and decent pay, ${ }^{10}$ while the global buyer could be seen as causing or contributing to the human rights violation. ${ }^{11}$

Both types of relationship are considered here as examples of transnational business activities with implications for human rights. The scenarios involve four players with different human rights obligations: two companies and two states. The two companies are, on the one hand, the local subsidiary or local supplier and, on the other hand, the mother company or global ordering company. While the former are often located in developing countries, the latter often have their domiciles in industrialised countries.

The two states involved in these scenarios are the 'host' state and the 'home state' ${ }^{12}$ The state on whose territory the business activity of the subsidiary or the local supplier is located is usually called the 'host state'. However, it should be noted that the term is misleading. It originates from the language of foreign direct investment, which considers the state in which the investment takes place

${ }^{8}$ An example of this type of scenario would be the pollution of the Niger Delta in Nigeria by Shell Nigeria and the responsibility of its mother company, Shell Netherlands, see Liesbeth Enneking, 'Transnational Human Rights and Environmental Litigation - A Study of Case Law Relating to Shell in Nigeria' in Isabel Feichtner, Markus Krajewski and Ricarda Roesch (eds), Human Rights in the Extractive Industries: Transparency, Participation, Resistance (Springer, forthcoming).

${ }^{9}$ Muchlinski, above n 1, 52-6.

${ }^{10}$ As established in, inter alia, the International Covenant on Economic, Social and Cultural Rights, arts 6 and 7.

${ }^{11}$ An example of this type of scenario would be the responsibility of international textile companies regarding the collapse of the Rana Plaza in Bangladesh in 2013. See Justine Nolan, 'Rana Plaza: The Collapse of a Factory in Bangladesh and its Ramifications for the Global Garment Industry' in Dorothée Baumann-Pauly and Justine Nolan (eds), Business and Human Rights - From Principle to Practice (Routledge, 2016) 27-30.

${ }^{12}$ Muchlinski, above n 1, 83-4. 
as 'host'. Nevertheless, the term will be used here in accordance with the terminology generally used. As will be shown in the next Part, the host state has a human rights obligation to protect individuals against human rights violations by other private entities through adopting, implementing and enforcing relevant regulation such as labour, safety and environmental laws and through providing effective judicial remedies.

The state in which the main seat of the mother company or the global buyer is located is the 'home state'. Again, the term is misleading, but will be used for practical reasons. Whether or not a home state also has human rights obligations in a transnational business context — in particular a duty to regulate transnational business activities or to provide judicial remedies for the victims - will be the main question addressed in this article.

\section{ScOpe ANd ApPlication Of Human Rights in a TRANSNATIONAL BUSINESS CONTEXT}

\section{A Human Rights Obligations of States and Multinational Enterprises}

International human rights norms are based on global and regional human rights treaties and on customary international law. ${ }^{13}$ These norms are formally binding only on states as the primary subjects of public international law and hence the primary duty-bearers of international human rights. Non-state actors, including multinational enterprises or other business enterprises, are not bound by international human rights law as they are typically not seen as subjects of international law. ${ }^{14}$

This does not mean that enterprises which are engaged in transnational business activities escape any binding obligations. Obligations of enterprises, such as the obligation to maintain proper labour and employment conditions, the health and safety of the population and the environment are usually established in domestic law and often based on international norms and standards. It is important to realise that international human rights norms may require states to adopt and implement regulations, yet these international norms and standards

\footnotetext{
${ }^{13}$ Christine Chinkin, 'Sources' in Daniel Moeckli, Sangeeta Shah and Sandesh Sivakumaran (eds), International Human Rights Law (Oxford University Press, $\left.3^{\text {rd }} \mathrm{ed}, 2017\right) 75$.

${ }^{14}$ Gatto, above n 1, 93; Crawford, above n 1, 122; Muchlinski, above n 1, 515.
} 
are not themselves binding on multinational enterprises or, for that matter, any other business entities.

Attempts to create binding norms for multinational enterprises have so far failed at the international level. ${ }^{15}$ However, various international non-binding standards establish a corporate responsibility to respect human rights. The most prominent international standard in this regard is the United Nations Guiding Principles for Business and Human Rights developed by the UN Special Representative, John Ruggie, and adopted by the UN Human Rights Council in $2011 .^{16}$ This framework of principles consists of three pillars, 1) the state duty to protect, 2) the corporate responsibility to respect, and 3) access to remedies. It urges companies to engage in human rights due diligence in order to avoid contributing - directly or indirectly — to human rights violations. Other important standards which partly build on the UN Guiding Principles are the OECD Guidelines for Multinational Enterprises and the recently revised ILO's Tripartite Declaration of Principles concerning Multinational Enterprises and Social Policy.

Contemporary international human rights law doctrine distinguishes three different dimensions of state obligations arising from international human rights treaties: 1) the duty to respect, 2) the duty to protect, and 3) the duty to fulfil. This trichotomy was originally developed by the Committee on Economic, Social and Cultural Rights, but it is now accepted by other treaty organs and received favourably in the literature. ${ }^{17}$

The duty to respect prohibits direct interference by the state in areas protected by human rights. It is therefore structured as a right directed against state measures and requiring the state to terminate or withdraw such measures. ${ }^{18}$ The duty to protect requires state measures - on the legislative, administrative or judicial levels - to protect human rights against violations and abuses by third parties. ${ }^{19}$ Hence, the duty to protect also forms a basis for state regulations of business activities. The duty to fulfil requires the state to ensure that the

15 David Weissbrodt and Muria Kruger, 'Norms on the Responsibilities of Transnational Corporations and Other Business Enterprises with Regard to Human Rights' (2003) 97 American Journal of International Law 901; Detlev F Vagts, 'The UN Norms for Transnational Corporations' (2003) 16 Leiden Journal of International Law 795.

${ }^{16}$ Guiding Principles, above $\mathrm{n} 4$.

${ }^{17}$ Olivier de Schutter, International Human Rights Law (Cambridge University Press, $2^{\text {nd }}$ ed, 2014) 279-90; Frédéric Mégret, 'Nature of Obligations' in Daniel Moeckli, Sangeeta Shah and Sandesh Sivakumaran (eds), International Human Rights Law (Oxford University Press, $3^{\text {rd }}$ ed, 2017) 101.

${ }^{18}$ Mégret, above n 17, 102.

${ }^{19}$ Ibid. 
substantive contents of rights are fulfilled, either through encouraging and enabling others to provide certain basic services and infrastructure (schools, hospitals, water and sanitation, and so forth) or through providing these services and infrastructure directly. ${ }^{20}$ For the purposes of the present analysis, the duty to protect is the most relevant state obligation, which is why the remainder of this article will focus on this dimension only.

The duty to protect requires the state to adopt and implement effective measures to prevent human rights violations by third parties. According to established jurisprudence of the treaty bodies monitoring the implementation of the different human rights treaties, this also includes the adoption and implementation of laws preventing or mitigating human rights violations. ${ }^{21}$ This involves civil and criminal provisions with adequate sanctions ${ }^{22}$ as well as labour, health and security regulations. A state violates its human rights obligations if it refuses to grant protection to individuals in cases of negative impacts on the human rights of these individuals. Consequently, the state is not only required to adopt laws, but also to ensure their effective implementation and enforcement through the administrative bodies and courts of that state. Finally, the state must monitor the protection it offers, especially after a new law is passed, to ensure it is effective.

The duty to protect is borne by the state in which the human rights violations took place. This state has all regulatory powers at its disposal based on the principle of territorial jurisdiction. ${ }^{23}$ Based on this, the state can exercise control over local companies as well as subsidiaries and branches of multinational enterprises based on its territory. The territorial state can therefore also regulate the activities of multinational enterprises and impose labour, health, safety and environmental requirements on them. If the subsidiaries of a multinational enterprise are incorporated under domestic law — which is often the case the state can also exercise regulatory powers based on the principle of personal jurisdiction.

\footnotetext{
${ }^{20}$ Ibid 103.

${ }^{21}$ Human Rights Committee, General Comment No 31, The Nature of the General Legal Obligation Imposed on States Parties to the Covenant, UN Doc CCPR/C/21/Rev.1/Add. 13 (26 May 2004) para 7; Committee on Economic, Social and Cultural Rights, General Comment No 20, Non-discrimination in Economic, Social and Cultural Rights (art 2, para 2, of the International Covenant on Economic, Social and Cultural Rights), UN Doc E/C.12/GC/20 (2 July 2009) para 11.

${ }^{22}$ Silidain v France (European Court of Human Rights, Application No 73316/01, 26 July 2005) [89] with further references.

${ }^{23}$ Muchlinski, above n 1, 83.
} 
Despite the significant regulatory competences of the territorial state, its actual capacities to implement and enforce the respective legislation are often limited. ${ }^{24}$ This is especially the case in states with structurally weak legal and administrative systems which are often not able to effectively control transnational business activities, or are unwilling to do so because of the fear of discouraging foreign investors. Frequently corruption exacerbates the problem. This is why the fulfilment of the territorial state's duty to protect is often inefficient from a human rights perspective. As a consequence, many have argued that the so-called home states should bear a greater responsibility in this regard. ${ }^{25}$ However, this raises the question of whether the home states have the competence to regulate the activities of business enterprises even if those activities occur outside of the territory of the regulating state.

\section{B Territorial and Extraterritorial Scope}

Human rights generally apply subject to the jurisdiction of the state in question. ${ }^{26}$ As mentioned above, states exercise full jurisdiction over their entire territory by virtue of territorial sovereignty. Hence, all individuals who are physically on the state's territory are protected by whichever human rights are enshrined in the law of that state.

Under general international law it is accepted that states may exercise jurisdiction outside of their territory. This is the case for ships sailing under the state's flag as per article 92 paragraph 1 of the United Nations Convention of the Law of the Seas or in the case of a military occupation. ${ }^{27}$ Moreover, human rights courts and treaty bodies have applied human rights treaties in situations in which the state exercised 'full and exclusive control' over an individual

\footnotetext{
${ }^{24}$ Marion Weschka, 'Human Rights and Multinational Enterprises: How Can Multinational Enterprises Be Held Responsible for Human Rights Violations Committed Abroad?' (2006) 66 Zeitschrift für ausländisches öffentliches Recht und Völkerrecht 625, 628-9.

${ }^{25}$ Sara L Seck, 'Conceptualizing the Home State Duty to Protect Human Rights' in Karin Buhmann, Lynn Roseberry and Mette Morsing (eds), Corporate Social and Human Rights Responsibilities (Palgrave Macmillan, 2011) 25; Wouter Vandenhole, 'Contextualising the State Duty to Protect Human Rights as Defined in the UN Guiding Principles on Business and Human Rights' [2012] Revista de Estudios Jurídicos 1.

${ }^{26}$ De Schutter, above n 17, 148; Sarah Joseph and Adam Fletcher, 'Scope of Application' in Daniel Moeckli, Sangeeta Shah and Sandesh Sivakumaran (eds), International Human Rights Law (Oxford University Press, $3^{\text {rd }}$ ed, 2017) 129.

${ }^{27}$ Loizidou v Turkey (European Court of Human Rights, Application No 15318/89, 18 December 1996; Ilascu v Moldova and Russia (European Court of Human Rights, Application No 48787/99, 8 July 2004) 48787/99; Legal Consequences of the Construction of a Wall in the Occupied Palestinian Territory (Advisory Opinion) [2004] ICJ Rep 136.
} 
outside the state's territory. ${ }^{28}$ The Human Rights Committee held as early as 1981 that human rights treaties apply if state agents abduct an individual and keep him or her in a foreign country. ${ }^{29}$

While these questions relate to the scope of the application of human rights, it is another question whether a state is obliged to regulate the activities of private actors if these activities have negative effects on the full enjoyment of human rights outside that state's territory. The UN Guiding Principles seem to take a conservative stand on this issue. Principle 2 states: 'States should set out clearly the expectation that all business enterprises domiciled in their territory and/or jurisdiction respect human rights throughout their operations.' The commentary to this principle explains:

At present States are not generally required under international human rights law to regulate the extraterritorial activities of businesses domiciled in their territory and/or jurisdiction. Nor are they generally prohibited from doing so, provided there is a recognized jurisdictional basis. Within these parameters some human rights treaty bodies recommend that home States take steps to prevent abuse abroad by business enterprises within their jurisdiction. ${ }^{30}$

The UN Guiding Principles therefore convey the view that states are allowed, but not obliged, to regulate the behaviour of private actors with respect to its impact on human rights abroad. ${ }^{31}$

Contrary to this, the Committee on Economic, Social and Cultural Rights (CESCR) - the body overseeing the International Covenant on Economic, Social and Cultural Rights — stated in its 2017 General Comment No 24 on Human Rights in the Context of Business Activities that, in its view, 'States Parties' obligations under the Covenant do not stop at their territorial borders.' Instead, the Committee was of the opinion that states

are required to take the necessary steps to prevent human rights violations abroad by corporations domiciled in their territory and/or jurisdiction (whether they are incorporated under their laws, or have their statutory seat,

\footnotetext{
${ }^{28}$ Hirsi Jamaa v Italy (European Court of Human Rights, Application No 27765, 23 February 2012) [73].

${ }^{29}$ Human Rights Committee, Views: Communication No R 12/52, UN Doc Supp No 40 (A/36/40) 176 (1981) para 12.1 (Lopez Burgos v Uruguay).

${ }^{30}$ Office of the High Commission on Human Rights, United Nations Guiding Principles on Business and Human Rights - Implementing the United Nations 'Protect, Respect and Remedy' Framework (United Nations, 2011) 3-4.

${ }^{31}$ For a critique of this approach see Olivier de Schutter, 'Towards a New Treaty on Business and Human Rights' (2016) 1 Business and Human Rights Journal 41, 45-6.
} 
central administration or principal place of business on the national territory), without infringing the sovereignty or diminishing the obligations of the host States under the Covenant. ${ }^{32}$

With respect to the duty to protect, the Committee stated that, even though states would normally not be directly internationally responsible for a violation of human rights caused by a private entity, a State party 'would be in breach of its obligations under the Covenant where the violation reveals a failure by the State to take reasonable measures that could have prevented the occurrence of the event'. ${ }^{33}$ Moreover,

[t]he responsibility of the State can be engaged in such circumstances even if other causes have also contributed to the occurrence of the violation, and even if the State had not foreseen that a violation would occur, provided such a violation was reasonably foreseeable. ${ }^{34}$

A few years earlier, the Committee on the Rights of the Child (CRC) stated a similar view in its General Comment No 16 on State Obligations regarding the Impact of the Business Sector on Children's Rights. ${ }^{35}$ The CRC stated that home states have obligations to respect, protect and fulfil children's rights in the context of businesses' extraterritorial activities and operations, 'provided that there is a reasonable link between the State and the conduct concerned' ${ }^{36}$ The CRC was of the opinion that such a reasonable link existed 'when a business enterprise has its centre of activity, is registered or domiciled or has its main place of business or substantial business activities in the State concerned'. ${ }^{37}$

As neither the commentary on the UN Guiding Principles on Business and Human Rights nor the CESCR in its General Comment No 24 offers a justification - based on human rights and general international law doctrine - of the views expressed, the next Part will attempt an analysis of this question.

\footnotetext{
${ }^{32}$ Committee on Economic, Social and Cultural Rights (CESCR), General Comment No 24 on State Obligations under the International Covenant on Economic, Social and Cultural Rights in the Context of Business Activities, UN Doc E/C.12/GC/24 (23 June 2017) para 26.

${ }^{33}$ CESCR, above n 32, para 32.

${ }^{34}$ Ibid.

${ }^{35}$ Committee on the Rights of the Child (CRC), General Comment No 16 (2013) on State Obligations regarding the Impact of the Business Sector on Children's Rights, UN Doc $\mathrm{CRC} / \mathrm{C} / \mathrm{GC} / 16$ (17 April 2013).

${ }^{36}$ Ibid para 43.

${ }^{37}$ Ibid.
} 


\section{Home State Duty to Regulate Transnational BUSINESS ACTIVITIES}

\section{A Home State Regulation as Reaction to Regulatory Failure in Host States?}

As pointed out above, it is regularly argued that host states often lack the necessary governance capacities or willingness to enforce laws addressing social, labour and environmental concerns. Furthermore, those states are threatened with the withdrawal of business if strong protective standards are enforced, a threat known as the 'race-to-the-bottom' threat. The perceived inability or unwillingness of host states to discharge their human rights duties leads, in the view of commentators, to a significant gap in the traditional, territorial approach to protecting human rights. ${ }^{38}$ It should also be kept in mind that, regardless of the host state's capacity, it can only target the local subsidiary or supplier which is often the weaker partner. Unlike the supplier, the mother company of a multinational enterprise, or the ordering company in a global supply chain, typically remains outside of the reach of the host state. However, it is this company that is often the more powerful global player and that also bears responsibility for situations in which human rights violations occur. This is why many human rights activists and scholars have argued for a responsibility to be placed on home states as they have a direct influence on, and jurisdiction over, mother companies or global ordering companies based on principles of personal and territorial jurisdiction.

However, if the duty of home states to protect against human rights violations in transnational business contexts is predominantly justified by reference to the deficiencies in the regulatory and judicial systems of host states, the foundation of home state responsibility lacks a crucial element. Home states bear an independent obligation to regulate to protect human rights because of their own responsibility. Home states also benefit from global supply chains and from the structure of multinational enterprises, and this benefit is created partly because the human rights risks created by transnational business are shifted to the countries of production, that is, the host states. The case for a home state duty to regulate transnational business activities rests therefore not only - and perhaps not at all - on regulatory failure or judicial deficiencies in host states, but on the independent responsibility of home states. In fact, the home states'

38 Nadia Bernaz, Business and Human Rights: History, Law and Policy - Bridging the Accountability Gap (Routledge, 2017) 231; Daniel Augenstein, 'Paradise Lost: Sovereign State Interest, Global Resource Exploitation and the Politics of Human Rights' (2016) 27 European Journal of International Law 669, 682-3. 
unwillingness to regulate transnational business activities contributes to human rights violations in other countries. Human rights responsibility is established along the value chain in home and host states independently of each other.

The preceding arguments have presented the case for home state regulation on a human rights policy basis. However, such a case must also rest on a sound doctrinal base which will now be developed.

\section{B Doctrinal Basis in General International Law}

General public international law is based on the doctrine of territorial sovereignty. However, sovereignty under international law is not absolute. In fact, a state may not use its territory to harm another state. While the origin of the 'no harm' rule (sic utere tuo ut alienum non laedas) in Roman law is disputed, it is generally agreed that the principle is common to various property law regimes. ${ }^{39}$

The no harm rule in international law was articulated most prominently in the Trail Smelter arbitration. As early as 1941 the tribunal in that case stated that

no State has the right to use or permit the use of its territory in such a manner as to cause injury by fumes in or to the territory of another or the properties or persons therein, when the case is of serious consequence and the injury is established by clear and convincing evidence. ${ }^{40}$

The principle that a state may not use its territory, or allow the use of its territory, to cause significant negative effects on the territory of other states is now considered an element of customary international environmental law. ${ }^{41}$

While the principle is well established in environmental law, it is less clear whether it can also be found in other areas of international law. ${ }^{42}$ In the Corfu Channel case the International Court of Justice (ICJ) established the no harm rule as a general principle of international law when it held that it was 'every State's obligation not to allow knowingly its territory to be used for acts

\footnotetext{
39 Jutta Brunnée, 'Sic utere tuo ut alienum non laedas', Max Planck Encyclopedia of Public International Law (March 2010) [2] <http://opil.ouplaw.com/home/EPIL>.

${ }^{40}$ Trail Smelter case (United States $v$ Canada) [1938, 1941] 3 UNRIAA 1905, 1965.

${ }^{41}$ Legality of the Threat or Use of Nuclear Weapons (Advisory Opinion) [1996] ICJ Rep 226 [29].

42 Brunnée, above n 39, [10]-[11].
} 
contrary to the rights of other States' ${ }^{43}$ This ruling clarifies that the no harm rule does not apply only between directly neighbouring states, but that every state has to be mindful of the rights of other states.

One manifestation of the no harm principle outside of international environmental law can be found in the international law against terrorism. The state's duties are twofold: 1) to prevent the infiltration of terrorists into, or residence in, the state's territories and 2) to refrain from giving refuge to, training, arming, financing or providing any facilities to, terrorists. These duties are based on the idea that the territory of one state may not be used by private parties to cause significant harm to other states. ${ }^{44}$ Similarly, general international criminal law requires that states do not give shelter to persons who have committed war crimes, crimes against humanity or genocide, but that states either extradite or prosecute them (aut dedere aut judicare). ${ }^{45}$

It may be too early to derive from the above principles a general and allencompassing principle of international law which requires the state to aim to prevent every significant negative effect on other states. Nevertheless, it is clear that one could argue that states are required to prevent individuals using their territories to conduct activities which have significant negative effects on other states. This principle could also be applied in the human rights context. Bartels seems to reject this view by arguing that the no harm rule 'applies only to harm caused by physical agents' and not to harm 'caused by a mere policy decision (by a state or a private actor) taken within the territory of an allegedly responsible state' ${ }^{46}$ However, the relevant international cases do not support this perspective. The decisive point in these cases was the lack of a state's action to prevent a private actor from engaging in harmful activity. There is no compelling reason why this principle could not be applied in the context of transnational business activities. However, it should be noted that there is no supporting practice by human rights courts or committees so far. ${ }^{47}$

\footnotetext{
${ }^{43}$ Corfu Channel (United Kingdom of Great Britain and Northern Ireland v Albania) (Judgment) [1949] ICJ Rep 4, 22.

${ }_{44}$ Pierre-Marie Dupuy and Cristina Hoss, 'Trail Smelter and Terrorism: International Mechanisms to Combat Transboundary Harm' in Rebecca M Bratspies and Russell A Miller (eds), Transboundary Harm in International Law: Lessons from the Trail Smelter Arbitration (Cambridge University Press, 2006) 225, 235.

${ }^{45}$ Michael P Scharf, 'Aut dedere aut iudicare' Max Planck Encyclopedia of Public International Law (June 2008) <http://opil.ouplaw.com/home/EPIL>.

46 Lorand Bartels, 'The EU's Human Rights Obligations in Relation to Policies with Extraterritorial Effects' (2014) 25 European Journal of International Law 1071, 1082. This view is supported by O'Brien, above $\mathrm{n} 2,72$.

${ }^{47}$ O’Brien, above n 2, 64-5.
} 


\section{Doctrinal Basis in Human Rights Law}

If one accepts a general obligation of states to ensure that their territory may not be used to cause significant harm to another state and if one connects this obligation to the general human rights duty to protect, it can be argued that a state is obliged to act if individuals in its territory cause significant harm to human rights on the territory of another state. ${ }^{48}$ The state can discharge this obligation by regulating the activities of businesses in a transnational context. While the no harm principle can be seen as the basis for such an obligation, it is unclear how far this obligation extends.

It should be noted that the question of the territorial reach of a human rights duty to protect needs to be distinguished from the question of the extraterritorial application of human rights or the jurisdictional scope of a human rights treaty as discussed above. Instead, it is a question of the scope of the duty to protect. From a general human rights perspective, it seems difficult to argue that this duty should be limited to the human rights of the individuals living on the territory of the state in question. If one were to accept this view, the environment in other states would be better protected through human rights than human beings are. There is, however, no normative or doctrinal principle which would support the idea that a state must not also take the rights of those into account who live outside of the territory of the state. In fact, the very idea of the universality of human rights suggests that there can be no reasonable argument for limiting the state's obligations to events occurring in its own territory. ${ }^{49}$

As a consequence, human rights need to be reconstructed as a relational and not as a territorial concept. ${ }^{50}$ The dominant question is not 'Where do human rights apply?' but rather 'Whom do human rights protect?' This could lead to a functional understanding of jurisdiction in human rights law instead of a territorial approach. It is worth recalling that, as early as 1981, the Human Rights Committee held in the famous Lopez Burgos case that the reference to jurisdiction in the International Covenant on Civil and Political Rights is 'not to the place where the violation occurred, but rather to the relationship between

\footnotetext{
${ }^{48}$ For a similar approach see Principle 25(a) of the Maastricht Principles on the Extraterritorial Obligations of States in the Area of Economic, Social and Cultural Rights, $<$ http://www.etoconsortium.org/en/main-navigation/library/maastricht-principles/> ('Maastricht Principles').

${ }^{49}$ See also Ibrahim Kanalan, 'Extraterritoriale Staatenpflichten jenseits der Hoheitsgewalt: Ein neues Konzept für umfassende extraterritoriale Staatenpflichten' (2014) 52 Archiv des Völkerrechts 495, 508-10.

${ }^{50}$ See also O'Brien, above n 2, 56-69 who refers to a 'spatial' and a 'personal model'.
} 
the individual and the State'. ${ }^{51}$ Jurisdiction could then be construed on the basis of the effectiveness of human rights protection. In other words, the state on whose territory a human rights violation occurs would have jurisdiction not due to the principle of territoriality, but because its activities would be the most effective way to mitigate or prevent human rights violations.

One of the key questions concerning any general state obligation to ensure that its territory is not used for significant human rights violations in other countries by private parties is when this obligation would arise. While the Committee on the Rights of the Child seemed to assume that any 'reasonable link' ${ }^{52}$ between the home state's acts (or failures to act) and the foreign violation would be sufficient, without specifying further the relationship between the home state and the violation, the Committee on Economic, Social and Cultural Rights relied on two conditions. ${ }^{53}$ First, the Committee asserted, it needs to be shown that an activity of the home state could have prevented the human rights violation in the other state. Second, the connection between the human rights violation and the failure of the state to act had to be foreseeable. The Committee used the risk of human rights violations associated with the extractive industries, especially mining - a sector which is notorious for human rights violations - as an example of a generally foreseeable risk. ${ }^{54}$

Based on this approach it can be argued that a state is required in the above circumstances to take regulatory measures, involving legislative, administrative and judicial activities, to prevent human rights violations in other countries. Effective human rights protection, in short, requires state actions if adverse human rights effects in other countries caused by private actors are predictable and preventable. ${ }^{55}$

Arguably, this approach is in line with the no harm principle discussed above, because a violation of human rights can be seen as harm done to another

\footnotetext{
${ }^{51}$ Human Rights Committee, above n 29, para 12.1.

${ }^{52}$ CRC, above n 35, para 43.

${ }^{53}$ CESCR, above $\mathrm{n} 32$, para 32.

${ }^{54}$ Ibid.

${ }^{55}$ A similar approach can be found in the Maastricht Principles, above n 48, Principle 9: 'A State has obligations to respect, protect and fulfil economic, social and cultural rights in any of the following: a) situations over which it exercises authority or effective control whether or not such control is exercised in accordance with international law; b) situations over which State acts or omissions bring about foreseeable effects on the enjoyment of economic, social and cultural rights, whether within or outside its territory; c) situations in which the State, acting separately or jointly, whether through its executive, legislative or judicial branches, is in a position to exercise decisive influence or to take measures to realize economic, social and cultural rights extraterritorially in accordance with international law.'
} 
country. The no harm principle would add a third requirement to the notions of predictability and preventability. Minor human rights violations or negative effects on human rights in the host country would be insufficient to trigger the home state's responsibility. Rather, the human rights violation would need to be of a significant and serious nature. Direct violations of the right to life or other fundamental rights of physical integrity and human dignity would be of greater significance than indirect contributions to negative impacts on the environment.

\section{Principle of Non-Intervention as Limitation?}

It has sometimes been argued that establishing a state's duty to regulate transnational activities of business entities could be seen as an unwelcome interference in the internal affairs of the state where the human rights violation occurred. At the outset, it should be noted that regulating private actors which/who are domiciled in the regulating state is not an exercise of extraterritorial sovereignty. In its General Comment No 24, the CESCR rightly underlined the fact that,

although the imposition of such due diligence obligations does have impacts on situations located outside these States' national territories since potential violations of Covenant rights in global supply chains or in multinational groups of companies should be prevented or addressed, this does not imply the exercise of extraterritorial jurisdiction by the States concerned. ${ }^{56}$

Indeed, states may not regulate or exercise jurisdiction over activities on foreign territory without the consent of the state concerned unless they do so pursuant to some recognised exception to the territoriality principle such as the principle of universality in international criminal law.

While it is clear that regulating the foreign activities of private entities over which a state exercises jurisdiction cannot be regarded as the extraterritorial exercise of jurisdiction, it could still be asked whether the state is unduly influencing the political, economic or legal system of another state to an extent which would be considered a violation of the principle of non-intervention. As clearly stated in the UN General Assembly's Friendly Relations Resolution of 1970 '[e]very State has an inalienable right to choose its political, economic, social and cultural systems, without interference in any form by another

${ }^{56}$ CESCR, above n 32, para 33. 
State. ${ }^{57}$ Consequently, states are not allowed to 'intervene, directly or indirectly, for any reason whatever, in the internal or external affairs of any other State'. ${ }^{58}$ This prohibition includes all forms of interference in the political, economic and cultural elements of the personality of the state. Also, states may not

use or encourage the use of economic political or any other type of measures to coerce another State in order to obtain from it the subordination of the exercise of its sovereign rights and to secure from it advantages of any kind. ${ }^{59}$

However, the principle of non-intervention does not contain an absolute prohibition of any influence exercised by one state over another state if the former acts within the boundaries of international law. In its famous Nicaragua judgment, the ICJ held that an intervention is only prohibited if it bears

on matters in which each State is permitted, by the principle of State sovereignty, to decide freely. One of these is the choice of a political, economic, social and cultural system, and the formulation of foreign policy. ${ }^{60}$

Unless the intervention is conducted using military means or other forms of coercion which are prohibited per se, an intervention is prohibited only if it relates to a matter that concerns solely the 'domestic affairs' of the target state. Broadly speaking, domestic affairs are all matters which are not covered by international obligations based on treaties or customary international law. ${ }^{61}$ As a consequence, a state may therefore not rely on the principle of nonintervention to reject interferences which aim at protecting fundamental human rights.

If one applies the above interpretation of the non-intervention principle to the state duty to regulate transnational business activities, it can be argued that a regulation requiring private entities to ensure their subsidiaries' or suppliers' adherence to the law of the state in which they operate - even if that law is not consistently applied or enforced in that state - would never be a violation of the principle of non-intervention. This is because respect for existing laws does

\footnotetext{
57 Declaration on Principles of International Law concerning Friendly Relations and Cooperation among States in accordance with the Charter of the United Nations, GA RES 2625, $25^{\text {th }}$ sess, $1883^{\text {rd }}$ plen $\mathrm{mtg}$, UN A/RES/25/2625 (24 October 1970).

${ }^{58}$ Ibid.

${ }^{59}$ Ibid.

${ }^{60}$ Military and Paramilitary Activities in and against Nicaragua (Nicaragua v United States of America) [1986] ICJ Rep 14 [205].

${ }^{61}$ Philip Kunig, 'Intervention, Prohibition of', Max Planck Encyclopedia of Public International Law (April 2008) [2] <http://opil.ouplaw.com/home/EPIL>.
} 
not negatively affect the social, political or economic system of a state. Matters are more difficult if the regulation of transnational business activities in the home state provides incentives for local companies in the host state to deviate from existing laws. Generally, it could be argued that an activity by one state which aims at producing non-compliance with existing domestic law in another state may amount to an intervention in the internal affairs of the other state. If, however, the laws of the other state violate the human rights obligations of that state the principle of non-intervention could not be invoked. For example, if a host state prohibits the formation of trade unions in violation of article 8 paragraph 1 of the International Covenant on Economic, Social and Cultural Rights, that state could not rely on the principle of non-intervention if another state engaged in activities which aimed at ensuring that the host state met its obligations under the relevant human rights treaty.

Only if, and to the extent that, a state is not bound by specific human rights obligations, including those arising under customary human rights law, might it be possible for that state to rely on the principle of non-intervention. In such a case, the non-intervention principle could indeed become a limitation on the right of other states to regulate transnational business activities. To use a concrete example: If State A prohibits corporation $\mathrm{X}$, which is domiciled in its territory, from concluding contracts with corporation $\mathrm{Y}$ in State B unless trade unions are able to operate freely in corporation $\mathrm{Y}$, and if trade unions are prohibited in State B, then State A's prohibition could be seen as an intervention in the internal affairs of State B if the prohibition of trade unions does not violate State B's obligations under international human rights law.

\section{E State Duty to Regulate Transnational Business Activities in the Draft of an International Legally Binding Instrument on Business and Human Rights}

One of the most interesting and innovative developments in the context of business and human rights concerns the re-emergence of the idea of creating binding obligations for business entities through an international human rights law instrument. ${ }^{62}$ In 2014, the United Nations Human Rights Council established an open-ended intergovernmental working group (OEIGWG) on transnational corporations and other business enterprises with respect to human rights and gave it the mandate 'to elaborate an international legally binding instrument to regulate, in international human rights law, the activities of

\footnotetext{
${ }^{62}$ See David Bilchitz, 'The Necessity for a Business and Human Rights Treaty' (2016) 1 Business and Human Rights Journal 203; Surya Deva and David Bilchitz (eds), Building a Treaty on Business and Human Rights: Context and Contours (Cambridge University Press, 2017).
} 
transnational corporations and other business enterprises' ${ }^{63}$ The OEIGWG held two sessions in 2015 and 2016 devoted to information sharing and deliberation. ${ }^{64}$ Prior to the third session in 2017, the Chair of the OEIGWG published a paper which outlined the possible elements of a treaty on business and human rights (the 'Elements Paper') ${ }^{65}$ Based on this paper, the OEIGWG held a number of formal and informal sessions and discussed the potential elements of a binding treaty even though a number of countries and the EU still oppose the establishment of a binding legal instrument.

In July 2018, the Chair of the OEIGWG published a so-called 'Zero Draft' of an international legally binding instrument to regulate, in international human rights law, the activities of transnational corporations and other business enterprises. ${ }^{66}$ Even though this draft will only be the basis for future negotiations and it is hence unclear whether, and to what extent, elements of the draft will become parts of a treaty, it is noteworthy that certain provisions of the draft can be read as a codification of the state duty to regulate transnational business activities with respect to human rights.

\section{Article 9 paragraph 1 of the Zero Draft on 'Prevention' obliges states to}

ensure in their domestic legislation that all persons with business activities of transnational character within such State Parties' territory or otherwise under their jurisdiction or control shall undertake due diligence obligations throughout such business activities...

${ }^{63}$ Human Rights Council, Elaboration of an International Legally Binding Instrument on Transnational Corporations and Other Business Enterprises with respect to Human Rights, UN Doc A/HRC/RES/26/9 (14 July 2014) 2 [1].

${ }^{64}$ Carlos Lopez, 'Struggling to Take Off?: The Second Session of Intergovernmental Negotiations on a Treaty on Business and Human Rights' (2017) 2 Business and Human Rights Journal 365.

${ }^{65}$ Open-Ended Intergovernmental Working Group on Transnational Corporations and Other Business Enterprises with Respect to Human Rights, Elements for a Draft Legally Binding Instrument on Transnational Corporations and Other Business Enterprises with Respect to Human Rights, (29 September 2017) <http://www.ohchr.org/Documents/HRBodies/ HRCouncil/WGTransCorp/Session3/LegallyBindingInstrumentTNCs_OBEs.pdf $>$. On the third session see also Doug Cassel, 'The Third Session of the UN Intergovernmental Working Group on a Business and Human Rights Treaty' (2018) 3 Business and Human Rights Journal 277.

${ }^{66}$ Open-Ended Intergovernmental Working Group on Transnational Corporations and Other Business Enterprises with Respect to Human Rights, Legally Binding Instrument to Regulate, in International Human Rights Law, the Activities of Transnational Corporations and Other Business Enterprises, Zero Draft of 16 July $2018<\mathrm{https} / / /$ www.ohchr.org/Documents/ HRBodies/HRCouncil/WGTransCorp/Session3/DraftLBI.pdf $>$. 
Furthermore, article 10 paragraph 1 of the Zero Draft on 'Legal Liability' states that:

State Parties shall ensure through their domestic law that natural and legal persons may be held criminally, civil [sic] or administratively liable for violations of human rights undertaken in the context of business activities of transnational character.

In particular, according to paragraph 6 of article 10:

All persons with business activities of a transnational character shall be liable for harm caused by violations of human rights arising in the context of their business activities, including throughout their operations,

a. to the extent it [sic] exercises control over the operations, or

b. to the extent it [sic] exhibits a sufficiently close relation with its subsidiary or entity in its supply chain and where there is strong and direct connection between its conduct and the wrong suffered by the victim, or

c. to the extent risk have [sic] been foreseen or should have been foreseen of human rights violations within its chain of economic activity.

'Business activities of a transnational character' are defined in article 4 paragraph 2 of the Zero Draft as economic activities 'that take place or involve actions, persons or impact in two or more national jurisdictions'.

These provisions would require state parties to the proposed treaty to adopt and implement legislation which requires business entities to undertake human rights due diligence in all areas of their business activities, including their supply chains, and to adopt and implement legislation which establishes the liability of business entities for harm caused by human rights violations. As it is clear that the treaty would apply to business activities of a transnational character, the provisions oblige states to regulate business activities in light of their impact on human rights outside of the territory of the regulating state. Read together, these provisions establish a state duty to protect against human rights violations caused or contributed to by business actors in a transnational context. ${ }^{67}$ Regardless of whether the draft will materialise as an international

\footnotetext{
${ }^{67}$ For a similar assessment see Surya Deva, 'The Zero Draft of the Proposed Business and Human Rights Treaty', Part II: 'On the Right Track, But Not Ready Yet' in Business and Human Rights Resource Centre, Reflections on the Zero Draft Blog Series <https://www.businesshumanrights.org/en/the-zero-draft-of-the-proposed-business-and-human-rights-treaty-part-iion-the-right-track-but-not-ready-yet>.
} 
agreement or whether it will suffer the same fate as earlier attempts to create binding norms for transnational corporations, the draft is clear evidence of a trend towards clarifying and articulating the state duty to protect against human rights violations in transnational business contexts.

\section{Approaches in State Practice}

Even though international human rights law still falls short of an explicit recognition of the state duty to protect against human rights violations through transnational business activities, recent developments in state practice concerning business and human rights provide examples of how states could discharge such an obligation. Three broad trends are emerging. The first approach relies on civil liability in the states where mother companies or global ordering companies are domiciled. While there have been many high-profile cases in recent years, it is still unclear if any civil case has ever led to the establishment of company liability. The second approach focuses on transparency and disclosure obligations, requiring businesses to report whether and, if so, how they have encountered and addressed human rights violations and risks thereof in their business relations. Finally, the third approach involves domestic regulations which specifically establish rules on how companies should conduct human rights due diligence and live up to their human rights responsibilities. These will be discussed in turn below.

\section{A Civil Liability}

Over the last fifteen to twenty years claimants have filed human rights writs in courts of the home states of multinational companies, with varying degrees of success. Usually, the claims were based on tort law. They argued that mother companies or lead companies in global supply chains had caused violations of life, physical integrity or property through the activities of their subsidiaries or suppliers in other countries. The liability of the mother companies or lead companies was based on the contributions of these companies to the situation or events that led to the respective torts. ${ }^{68}$

The first and hitherto most prominent cases were based on an old US law, the Alien Tort Statute (ATS) (also known as the Alien Tort Claims Act or ATCA). ${ }^{69}$

\footnotetext{
${ }^{68}$ Muzaffer Eroglu, Multinational Enterprises and Tort Liabilities (Edward Elgar, 2008); Simon Baughen, Human Rights and Corporate Wrongs (Edward Elgar, 2015).

${ }^{69}$ See Jan Wouters, Leen De Smet and Cedric Ryngaert, Multinational Companies for Foreign Human Rights Violations Committed Abroad: Lessons from the Alien Tort Claims Act? Institute for International Law K U Leuven, Working Paper No 46, November 2003; Michael Koebele,
} 
According to this law, which was enacted in 1789, the US District Courts have original jurisdiction over civil actions by foreigners for torts 'committed in violation of the law of nations or a treaty of the United States.' ${ }^{70}$ Until the $1980 \mathrm{~s}$ the law was hardly ever used and not known to many. However, it was then used to found claims by victims of torture from abroad against their torturers who had taken up residence in the US. ${ }^{71}$ From the early 2000 s claimants began to use the ATS as a basis for law suits against US and foreign corporations because of their alleged contributions to violations of human rights and environmental standards. ${ }^{72}$ Even though most cases did not lead to final judgments against corporate defendants, litigation based on the ATS continued for more than a decade until the US Supreme Court held in two landmark cases that the ATS could not be used against corporations and would not apply in situations which had no connection to US territory. ${ }^{73}$ While these judgments foreclosed any further actions based on the ATS in federal courts, human rights litigation in the US may continue on the basis of state tort law and in state courts. $^{74}$

Victims of human rights violations have also started to issue proceedings in the courts of Europe and elsewhere. Examples include tort litigation against multinational enterprises in English courts, ${ }^{75}$ claims filed in the Netherlands against Royal Dutch Shell plc, ${ }^{76}$ and a lawsuit against the German textile company $\mathrm{KiK}$ in the Dortmund regional court. ${ }^{77}$

There have also been arguments that, in addition to, or instead of, tortious liability, directors or CEOs of companies which have been connected with

Corporate Responsibility under the Alien Tort Statute - Enforcement of International Law through US Torts Law (Brill, 2009).

7028 US Code $\S 1350$.

${ }^{71}$ The landmark case was Filártiga $v$ Peña-Irala, $630 \mathrm{~F} 2 \mathrm{~d} 876$ ( $\left.2^{\text {nd }} \mathrm{Cir}, 1980\right)$.

72 Doe v Unocal, 248 F3d 915 (9 $9^{\text {th }}$ Cir, 2002)

${ }^{73}$ Kiobel v Royal Dutch Petroleum Co, 569 US 108 (2013); Jesner v Arab Bank, PLC, 584 US, 16-499 (2018).

${ }^{74}$ Seth Davis and Christopher A Whytock, 'State Remedies for Human Rights' (2018) 98 Boston University Law Review 397, 401.

${ }^{75}$ See, for example, High Court of Justice, Lungowe v Vedanta [2016] EWHC 975 (TCC) and Okpabi v Royal Dutch Shell [2018] EWCA Civ 191. On this and other cases see Ekaterina Aristova, 'Tort Litigation against Transnational Corporations in the English Courts: The Challenge of Jurisdiction' (2018) 14(2) Utrecht Law Review 6.

${ }^{76}$ Gerechtshof Den Haag, Milieudefensie v Royal Dutch Shell, ECLI:NL:GHDHA:2015:3587.

${ }^{77}$ For a discussion of this and other cases see Matthias Weller and Alexia Pato, 'Local Parents as "Anchor Defendants" in European Courts for Claims against Their Foreign Subsidiaries in Human Rights and Environmental Damages Litigation: Recent Case Law and Legislative Trends' (2018) 23 Uniform Law Review 397. 
human rights violations could be held accountable on the basis of corporate liability. ${ }^{78}$ The key question is whether the duty of care of directors or managers towards the corporation or the shareholders includes a duty to respect human rights. According to conventional approaches, directors' and managers' duties are only concerned with the monetary value of the company and not its reputation or impact on its stakeholders. ${ }^{79}$ If, however, the nature of a corporation is not reduced to pecuniary interests, it could be argued that the decision-makers in a company are also responsible for its corporate conduct in relation to human rights.

\section{B Transparency and Disclosure}

Another approach - arguably the least intrusive - concerns the requirements of transparency and disclosure in relation to a company's transnational business activities. ${ }^{80}$ Broadly speaking, the obligations in this category include the duty to disclose certain facts, connections and information relating to the observance of human rights by the company and its subsidiaries and within its supply chain. Transparency requirements of this kind pertain not only to human rights but extend to other obligations arising from Corporate Social Responsibility $(\mathrm{CSR}) .{ }^{81}$

Disclosure obligations gained attention for the first time in the context of human rights when the so-called Dodd-Frank Act was adopted in the US in $2010{ }^{82}$ One aspect of this law, which was predominantly a reaction to the financial crisis of 2007 and 2008, concerned so-called conflict minerals from the Democratic Republic of Congo (DRC). ${ }^{83}$ According to the Dodd-Frank Act, companies listed on the stock exchange were required to report publicly if certain conflict minerals were traded in their supply chains and if these minerals were from the DRC or neighbouring states. They were to report which due diligence measures had been adopted at the mining site and throughout the

\footnotetext{
${ }^{78}$ See, with regard to CSR and English corporate law, Andreas Rühmkorf, Corporate Social Responsibility, Private Law and Global Supply Chains (Edward Elgar, 2015) 39-52.

${ }^{79}$ Rühmkorf, above n 78, 32-9.

${ }^{80}$ Bernaz, above n 38, 251-2.

${ }^{81}$ Justine Nolan, 'Hardening Soft Law: Are the Emerging Corporate Social Disclosure Laws Capable of Generating Substantive Compliance with Human Rights' (2018) 15 Brazilian Journal of International Law 65.

${ }^{82}$ Dodd-Frank Wall Street Reform and Consumer Protection Act, Pub L No 111-203, § 1502, 124 Stat 1376, 2213-18 (2010).

${ }^{83}$ Christiana Ochoa and Patrick J Keenan, 'Regulating Information Flows, Regulating Conflict: An Analysis of United States Conflict Minerals Legislation' (2011) 1 Goettingen Journal of International Law 129.
} 
supply chain. ${ }^{84}$ This approach was therefore restricted to certain products and a certain region and hence also to very specific human rights violations.

Similar transparency requirements - also limited to particular situations or human rights violations - can be found in the UK Modern Slavery Act $2015^{85}$ and the California Transparency in Supply Chains Act. ${ }^{86}$ Both laws require that companies of a certain size report whether there are instances of slavery or inhumane working conditions in their supply chain or whether there is a risk of such instances, and what the companies intend to do about it. A similar approach can be found in the proposed Law against Child Labour which is currently before the Dutch Parliament. ${ }^{87}$

The so-called EU CSR-Directive on Disclosure of Non-Financial and Diversity Information contains broader, but also more general, transparency requirements. ${ }^{88}$ This directive requires that corporations of a certain size include in their management report a non-financial statement containing information on the impact of their activities on environmental, social and employee matters, respect for human rights, and anti-corruption and bribery matters. In order to report on human rights matters, corporations may rely on international frameworks such as the UN Guiding Principles on Business and Human Rights, the OECD Guidelines for Multinational Enterprises, and the International Labour Organization's (ILO's) Tripartite Declaration of Principles concerning Multinational Enterprises and Social Policy. If companies do not rely on any of these standards, they need to explain this choice.

Transparency and disclosure requirements are regulatory instruments of limited intensity and intrusion. The affected companies need only to publish a declaration or statement and are not required to change their behaviour. While wrongful reporting may trigger liability, a potential claimant would have to

\footnotetext{
${ }^{84}$ For a critical analysis see Patrick Keenan, 'United States Law and Conflict Minerals' in Isabel Feichtner, Markus Krajewski and Ricarda Roesch (eds), Human Rights in the Extractive Industries: Transparency, Participation, Resistance (Springer, forthcoming).

85 Ryan Turner, 'Transnational Supply Chain Regulation: Extraterritorial Regulation as Corporate Law's New Frontier' (2016) 17 Melbourne Journal of International Law 188-209.

${ }^{86}$ Alexandra Prokopets, 'Trafficking in Information: Evaluating the Efficacy of the California Transparency in Supply Chains Act of 2010' (2014) 37 Hastings International and Comparative Law Review 351.

87 Eerste Kamer der Staten-General, Initiatiefvoorstel-Kuiken Wet zorgplicht kinderarbeid, $<$ https://www.eerstekamer.nl/wetsvoorstel/34506_initiatiefvoorstel_kuiken>.

${ }^{88}$ Directive 2014/95/EU of the European Parliament and of the Council of 22 October 2014 amending Directive 2013/34/EU as regards Disclosure of Non-Financial and Diversity Information by Certain Large Undertakings and Groups [2014] OJ L 330/1.
} 
show that damage had been caused by, or could be directly linked to, the wrongful reports. The main objective of transparency requirements is hence the information of consumers. ${ }^{89}$ While this may also have an indirect effect on the behaviour of the companies, the regulatory impact seems to be limited. ${ }^{90}$

\section{Due Diligence Requirements}

One of the key elements of the corporate obligation to respect human rights is the notion of human rights due diligence as stipulated in Principle 17 of the UN Guiding Principles on Business and Human Rights. ${ }^{91}$ While the Guiding Principles do not impose a legally binding obligation on companies to undertake human rights due diligence, calls for home state regulations to make human rights due diligence binding on companies are increasing. Such laws would oblige companies to assess human rights risks, investigate human rights abuses, adopt action plans and report on them.

The French law on due diligence for mother companies and international ordering companies, enacted in March 2017 (Loi relative au devoir de vigilance des sociétés mères et des entreprises donneuses d'ordre), ${ }^{92}$ is the first comprehensive law of this kind. It obliges companies of a certain size to adopt a due diligence plan (plan de vigilance) which has to identify the human rights risks in the corporation's own activities and in its supply chain. However, the law does not specify the details of such a plan. Instead it enables the Conseil d'Etat to adopt further regulations. Originally, the law also imposed fines on non-complying companies, but the French Conseil constitutionnel

\footnotetext{
${ }^{89}$ Prokopets, above n 86, 357.

90 Ibid 365.

91 'In order to identify, prevent, mitigate and account for how they address their adverse human rights impacts, business enterprises should carry out human rights due diligence. The process should include assessing actual and potential human rights impacts, integrating and acting upon the findings, tracking responses, and communicating how impacts are addressed. Human rights due diligence: (a) Should cover adverse human rights impacts that the business enterprise may cause or contribute to through its own activities, or which may be directly linked to its operations, products or services by its business relationships; (b) Will vary in complexity with the size of the business enterprise, the risk of severe human rights impacts, and the nature and context of its operations; (c) Should be ongoing, recognizing that the human rights risks may change over time as the business enterprise's operations and operating context evolve.'

92 Loi $n^{\circ} 2017-399$ du 27 mars 2017 relative au devoir de vigilance des sociétés mères et des entreprises donneuses d'ordre (France), JO, No 74, 28 March $2017<\mathrm{https} / /$ www. legifrance.gouv.fr/eli/loi/2017/3/27/2017-399/jo/texte>.
} 
[Constitutional Court] declared these to be unconstitutional. ${ }^{93}$ It will now be up to French courts in other proceedings, and to business practice, to determine further details.

Another example, which also establishes binding due diligence requirements but which is far less ambitious in scope and impact than the French law, is the EU regulation on supply chain due diligence obligations for Union importers of so-called 'conflict minerals' ${ }^{94}$ Similar to the Dodd-Frank Act, this regulation concerns conflict minerals from the Democratic Republic of Congo, but applies only to importers. Enterprises processing the relevant minerals are not covered by the Regulation. Unlike the Dodd-Frank Act, the EU regulation goes beyond imposing reporting requirements, obliging the companies to undertake concrete due diligence measures. ${ }^{95}$

\section{SUMMARY AND OUTLOOK}

This article has shown that there is a strong case to be made for the existence of a state duty to protect against human rights violations in the context of transnational business activities. This duty would apply to the regulation of mother companies in transnational corporate groups. These companies would be obliged to prevent their daughter companies either causing or contributing to human rights violations in other countries. The duty would also apply to the ordering companies in global supply chains, requiring that they prevent human rights violations associated with their local suppliers.

General public international law, as well as human rights doctrine, provide sufficient grounds to argue the existence of a home state duty to regulate corporate actors that violate human rights by their transnational business activities. It has been shown in this article that states have a duty to regulate the transnational business activities of corporations over which they exercise jurisdiction if the adverse human rights consequences of such activities are predictable and if appropriate regulation could contribute to the prevention of such adverse effects.

\footnotetext{
${ }^{93}$ Conseil constitutionnel [French Constitutional Court], decision $n^{\circ}$ 2017-750 DC, 23 March 2017 reported in JO, 28 March $2017<$ https://www.conseil-constitutionnel.fr/decision/ 2017/2017750DC.htm>.

${ }^{94}$ Regulation (EU) 2017/821 of the European Parliament and of the Council of 17 May 2017 Laying Down Supply Chain Due Diligence Obligations for Union Importers of Tin, Tantalum and Tungsten, Their Ores, and Gold Originating from Conflict-Affected and High-Risk Areas [2017] OJ L 130/1.

${ }^{95}$ Ibid arts 3-7.
} 
While the examples of jurisprudence and legislation affecting transnational business activities discussed in this article can be seen as possible articulations of a state duty to protect human rights in this context, it is unclear whether, and to what extent, the respective states have acted assuming that they are fulfilling a human rights obligation. Further research would be needed to show whether and, if so, how human rights considerations influence these and similar state approaches to the regulation of transnational business. 